\title{
Isolation and biochemical characterization of bradykinin-potentiating peptides from Bitis gabonica rhinoceros
}

\author{
Tamara M. Fucase ${ }^{1}$, Juliana M. Sciani ${ }^{2}$, Ingrid Cavalcante², Vincent L. Viala', Bruno B. Chagas', \\ Daniel C. Pimenta ${ }^{2}$ and Patrick J. Spencer ${ }^{1 *}$
}

\begin{abstract}
Background: Venoms represent a still underexplored reservoir of bioactive components that might mitigate or cure diseases in conditions in which conventional therapy is ineffective. The bradykinin-potentiating peptides (BPPs) comprise a class of angiotensin-I converting enzyme (ACE) inhibitors. The BPPs usually consist of oligopeptides with 5 to 13 residues with a high number of proline residues and the tripeptide lle-Pro-Pro (IPP-tripeptide) in the C-terminus region and have a conserved $\mathrm{N}$-terminal pyroglutamate residue. As a whole, the action of the BPPs on prey and snakebite victims results in the decrease of the blood pressure. The aim of this work was to isolate and characterize novel BPPs from the venom of Bitis gabonica rhinoceros.

Methods: The crude venom of $B$. g. rhinoceros was fractionated by size exclusion chromatography and the peptide fraction ( $<7 \mathrm{kDa}$ ) was separated by reverse phase chromatography (RP-HPLC) and analyzed by ESI-IT-TOF-MS/MS. One new BPP was identified, synthetized and assayed for ACE inhibition and, in vivo, for edema potentiation.

Results: Typical BPP signatures were identified in three RP-HPLC fractions. CID fragmentation presented the usual $y$-ion of the terminal P-P fragment as a predominant signal at $\mathrm{m} / \mathrm{z}$ 213.1. De novo peptide sequencing identified one Bothrops-like BPP and one new BPP sequence. The new BPP was synthesized and showed poor inhibition over ACE, but displayed significant bradykinin-induced edema potentiation.

Conclusions: So far, few BPPs are described in Viperinae, and based on the sequenced peptides, two non-canonical sequences were detected. The possible clinical role of this new peptides remains unclear.
\end{abstract}

Keywords: Peptide, Hypotension, Viperinae

\section{Background}

Snake venoms are a complex mixture of peptides and proteins, including peptidases. Many of these toxins mimic structurally and functionally endogenous molecules of the prey involved in homeostatic processes, escaping, however, from the regulation mechanisms, therefore disturbing physiological equilibrium. Besides snake venoms proteomics, several authors are now focusing on peptidomics with the aim of isolating new potential drugs [1-5]. Unlike proteins, peptides have the advantage of being small, easily synthetized and presenting low

\footnotetext{
* Correspondence: pspencer@ipen.br

${ }^{1}$ Biotechnology Center, Nuclear and Energy Research Institute (IPEN), Av. Lineu Prestes, 2242, São Paulo, SP CEP 05508-000, Brazil

Full list of author information is available at the end of the article
}

immunogenicity [6]. Due to their high degree of target specificity, venom toxins have been increasingly used as lead compounds in the development of drugs [7]. Biologically active proteins and peptides, as those found in venoms, may have a potential therapeutic use for the correction of hemostatic disorders and cellular adhesion among other applications [8]. Bradykinin (BK), which was first discovered by Rocha and Silva et al. in 1949 [9], can be described as the hydrolysis product of high molecular mass kininogen by plasma kallikrein $[10,11]$. This molecule has been associated to several physiological processes such as the inflammatory responses and induction of nociception and hyperalgesia [12].

The bradykinin-potentiating peptides (BPPs) comprise a class of angiotensin-I converting enzyme (ACE) inhibitors 
[13]. The somatic ACE is a dipeptidyl carboxypeptidase situated on the external surface of endothelial cells. This enzyme plays a central role in blood pressure regulation, is composed of two highly similar domains, the $\mathrm{N}$ - and Cdomains [14]. Each one of them contain an active site, characterized by the presence of a zinc-metallopeptidase HEXXH consensus motif $[15,16]$. ACE increases blood pressure by generating angiotensin II (Ang II) from angiotensin I and by inactivating BK [17]. The C-domain of mammalian ACE is mainly responsible for Ang II formation while $\mathrm{BK}$ is inactivated by both domains with the same efficiency [18].

Many BPPs were described in the venoms from arthropods, amphibians and snakes, most of them being ACE inhibitors [19]. In the case of BPPs isolated from snake venoms, these molecules are recognizable by a common structural pattern (Pyr-EXnPXPXIPP) - where Pyr is pyroglutamic acid and $\mathrm{X}$ is any amino acid residue whreas Cys, with the C-terminus sequence PXIPP, is crucial for the binding in the ACE catalytic site [7, 13].

Thereafter, BPPs were isolated from many snake venoms and shown to potentiate contraction in the isolated guinea pig ileum and to increase the hypotensive effect of BK, by inhibiting BK degradation [20]. The hypotensive effects of these BPPs were also associated with the inhibition of the conversion of angiotensin I to its active metabolite Ang II [21]. These crucial findings paved the way for the later development of ACE inhibitors, such as Captopril ${ }^{\circ}$, for the treatment of hypertension and heart failure $[22,23]$. In the present work, we describe the sequence of two BPPs (one new and one already described for Bothrops jararaca) isolated from the venom of Bitis gabonica rhinoceros and present an in vivo functional characterization of the synthetic analogue. The new BPP was termed BPP-10 g-AP.

\section{Methods}

\section{Animals}

Male Wistar (200 g-250 g) rats, bred at the Nuclear and Energy Research Institute (IPEN), São Paulo, SP, Brazil were used for the in vivo assays. The animals had access to food and water ad libitum, and were kept under a 12 h-light/dark cycle. Procedures involving animals and their care were in accordance with the guidelines for the use of animals on biomedical research and were approved by the Animal Ethics Committee (protocol 171/16) of IPEN.

\section{Drugs and reagents}

Acetonitrile (HPLC grade) was purchased from J. T. Baker (USA). Laboratory-deionized water was produced by a Milli-Q water purifying system (Millipore, USA), iodoacetamide, somatic ACE (rabbit lung) and BK acetate were purchased from Sigma-Aldrich (USA). The synthetic peptide APQERGPPEIPP was purchased from FastBio Ltda (Brazil).

\section{Peptide purification}

Crude venom of B. g. rhinoceros (30 mg) was fractionated by size exclusion chromatography (SEC) on a Superdex 75 column at $\mathrm{pH} 7.0$, using $0.1 \mathrm{M}$ ammonium bicarbonate buffer. The flow rate was of $0.6 \mathrm{~mL} / \mathrm{min}$. Based on retention times, the peaks with molecular mass lower than $7 \mathrm{kDa}$ were individually pooled and lyophilized.

The peak of interest (peak 9, Fig. 1) was injected in a $\mathrm{C}_{18}$ column $(4.6 \times 150 \mathrm{~mm}$ Sigma- Aldrich) using $0.1 \%$ $(\mathrm{v} / \mathrm{v})$ trifluoroacetic acid (TFA)/water (solution A) and 90\% acetonitrile/0.1\% TFA/water (solution B). Prior to injection, the column was equilibrated with $20 \%$ B. Elution was performed with a gradient of B solution $(90 \%$ acetonitrile/0.1\% TFA/water) ranging from 20 to $50 \%$, in $20 \mathrm{~min}$, at a flow rate of $1 \mathrm{~mL} / \mathrm{min}$. The peaks were manually collected.

\section{De novo peptide sequencing}

For mass spectrometric de novo peptide sequencing the samples were directly injected on the ESI-IT-TOF (Shimadzu Co., Japan), at $0.05 \mathrm{~mL} / \mathrm{min}$ constant flow rate, in positive mode, for MS, $\mathrm{MS}^{2}$ and $\mathrm{MS}^{3}$ analyses. The interface voltage was kept at $4.5 \mathrm{kV}$, the detector voltage at $1.8 \mathrm{kV}$ and the capillary temperature at $200{ }^{\circ} \mathrm{C}$. Data were collected at a range of 50-1800 m/z. For fragmentation, the precursor ions were selected under a $0.5 \mathrm{~m} / \mathrm{z}$ window, and the argon collision energy was kept at $50 \%$. The instrument control and data acquisition were performed with the LC-MS Solutions software (Shimadzu Co., Japan).

\section{ACE inhibition assay}

ACE inhibition was performed by continuously monitoring the hydrolysis of the fluorescence resonance energy transfer (FRET) substrate Abz-FRK(Dnp)P-OH (o-aminobenzoic acid-Phe-Arg- Lys(DNP)-Pro-OH), in the presence or absence of the synthetic inhibitor, as described by Carmona et al. [24]. Briefly, $0.5 \mathrm{mU}$ of ACE ( $1 \mathrm{mU}=$ nmol of substrate hydrolyzed per $\mathrm{min}$ ) was added to a buffered (100 mM Tris- $\mathrm{HCl}, 50 \mathrm{mM} \mathrm{NaCl}$ and $10 \mathrm{mM} \mathrm{ZnCl} \mathrm{2,} \mathrm{pH} \mathrm{7.0)} 2 \mu \mathrm{M}$ substrate solution, and the fluorescence $\left(\lambda_{\text {ex }}=320 \mathrm{~nm}, \lambda_{\mathrm{em}}=420 \mathrm{~nm}\right)$ was recorded after $5 \mathrm{~min}$ in the absence of the inhibitor. This value was considered $\mathrm{V}_{0}$. Increasing concentrations of the inhibitor were then added every $5 \mathrm{~min}$ and the fluorescence values were recorded. The inhibition constant was then calculated according to Carmona et al. [24].

\section{Bradykinin-potentiating activity in vivo}

Edema was induced by intraplantar injection of $2 \mathrm{ng}$ of BK diluted in $50 \mu \mathrm{L}$ saline into the left hind paw, which 


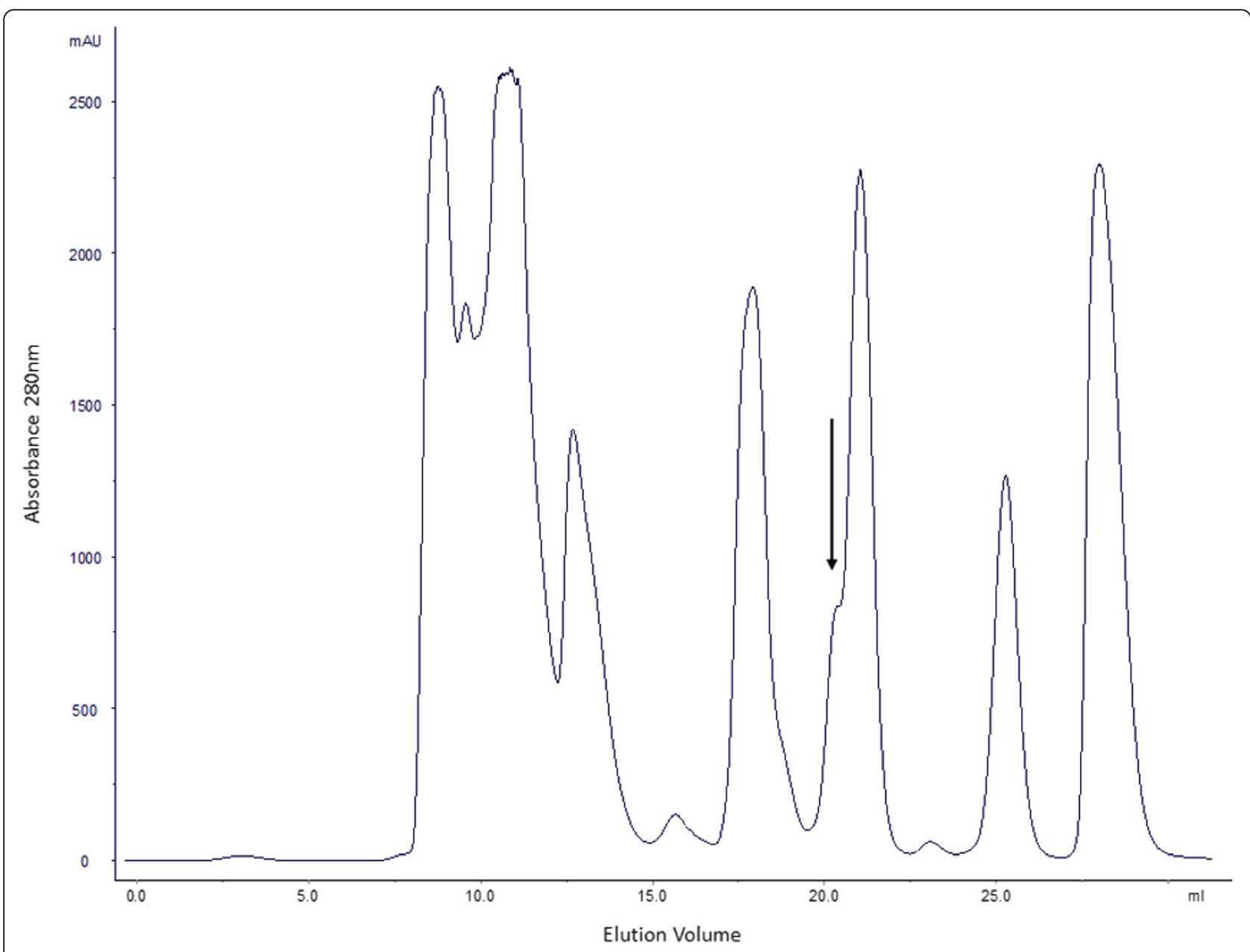

Fig. 1 Elution profile of $30 \mathrm{mg}$ of B. g. rhinoceros venom on a Superdex 75 10/300 column. The flow rate was of $0.6 \mathrm{~mL} / \mathrm{min}$. The arrow indicates the fraction (peak 9) that was further analyzed

was measured every $5 \mathrm{~min}$ for $40 \mathrm{~min}$ by a plethysmograph $(\mathrm{H}$. Basile, Italy). The right paw was injected with $50 \mu \mathrm{L} \mathrm{mL}$ saline $(\mathrm{NaCl} 0.9 \% \mathrm{w} / \mathrm{v})$. In parallel, a group was injected with the synthetic potentiating peptide (40 $\mathrm{ng} / \mathrm{mL}$ ) in the left paw 10 min before the injection of BK, in order to evaluate the potentiation of BK. In both cases, the volume of the right paw was subtracted from that of volume of the left paw, to give net edema, expressed in $\mu \mathrm{L}$.

\section{Statistical analysis}

One-way analysis of variance (ANOVA) was performed. The significance level was considered as $\mathrm{p}<0.05$.

\section{Results}

Purification and characterization of the peptide

The gel filtration of the crude venom resulted in eleven peaks (Fig. 1). The low molecular mass peak indicated by the arrow was pooled and lyophilized.
This fraction was then further decomplexed by reverse phase chromatography on a $\mathrm{C} 18$ column, resulting in three peaks (Fig. 2).

\section{Mass spectrometry and de novo sequencing}

The BPP-containing peak was analyzed by electrospray (MS; $\mathrm{MS}^{2}$ and $\mathrm{MS}^{3}$ were required for proper de novo sequencing). The interpreted annotated mass spectra are depicted below (Figs. 3 and 4).

The fragmentation of BPPs by collision-induced dissociation during electrospray tandem mass spectrometry analysis (ESI-MS/MS) generates a predominant signal at $\mathrm{m} / \mathrm{z} 213.1$ corresponding to the $y$-ion of the terminal Pro-Pro fragment [25]. This signature was observed in all spectra. The raw data were processed by Mascot (Matrix Science Inc., USA) and Peaks (Bioinformatics Solutions Inc., Canada). The de novo sequencing list of peptide was manually checked for accuracy. 


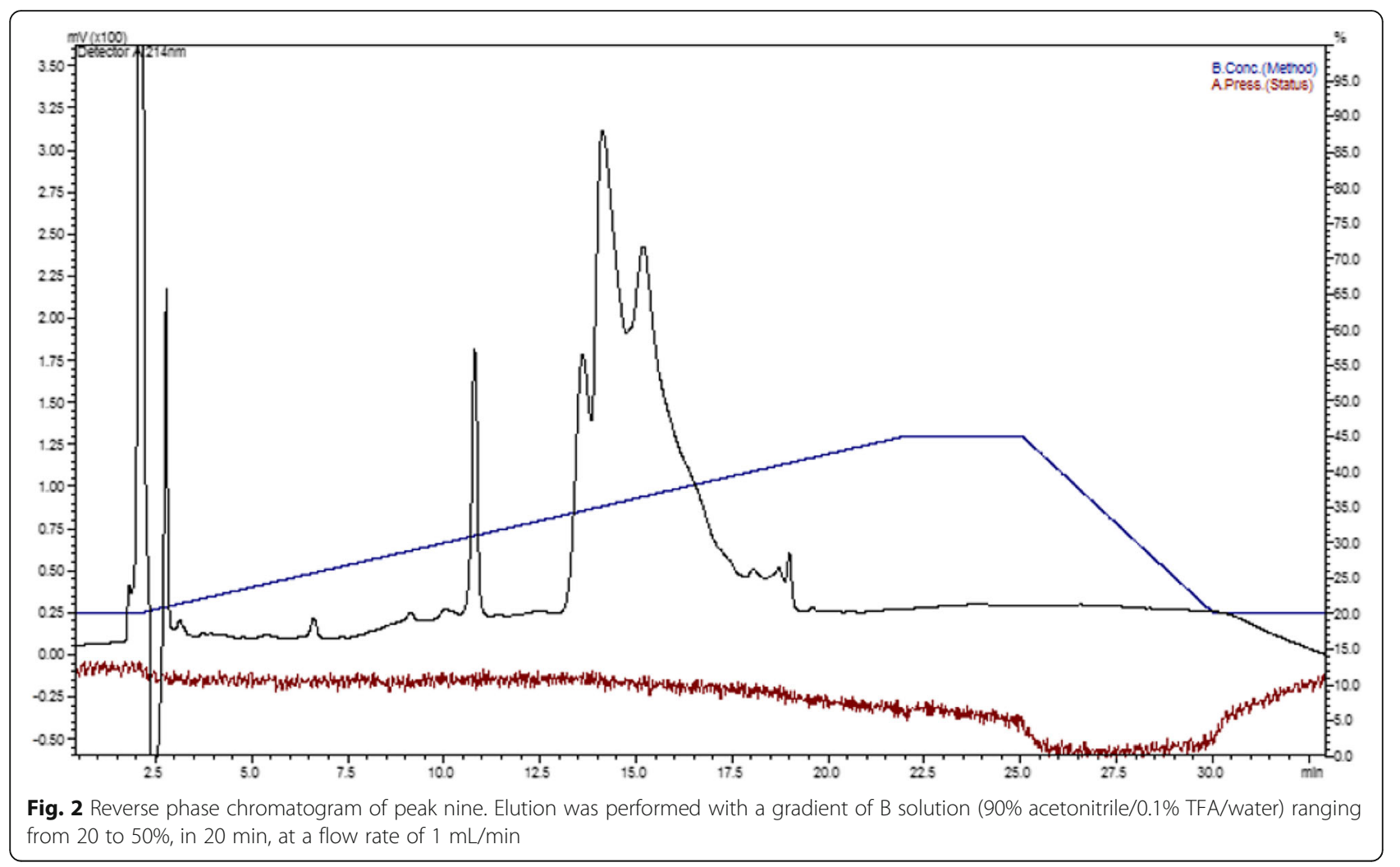

\section{Inhibition assay}

The hydrolysis rate of the synthetic substrate in the presence of different inhibitor concentrations resulted in a calculated Ki of $1 \mathrm{mM}$ (data not shown).

\section{Bradykinin-potentiating activity in vivo}

Based on the de novo sequence of the native BPP, a synthetic peptide was purchased for activity assays. BK potentiating activity was investigated indirectly through the rat paw edema assay. Figure 5 shows the time course of rat paw edema after intraplantar injection of $40 \mathrm{ng} / \mathrm{mL}$ BK. The induced edema was detectable after $5 \mathrm{~min}$ and then declined at a constant rate over the next $40 \mathrm{~min}$.

\section{Discussion}

Many venom peptides mimic both functionally and structurally human molecules with physiological activity. These venom peptides target receptors and molecules, interfering in vital physiological processes such as hemostasis, coagulation and blood pressure. Their high specificity, low molecular mass (and therefore low immunogenicity), structural stability and relative ease of synthesis turn these peptides into a promising source of new drugs [26-28].

Envenomation by Bitis sp. often results in severe local damage, hypotension, coagulopathy, thrombocytopenia and spontaneous local bleeding and, in the absence of antivenom therapy, the accident can be fatal.
Proteomic analyses showed that metallopeptidases, serine peptidases, disintegrins, L-aminoacid oxidase, Kunitz inhibitors, phospholipases $\mathrm{A}_{2}$, cystatins and Ctype lectins are present in Bitis venoms such as $B$. arietans and B. g. rhinoceros [27, 29]. Interestingly, the proteomic analysis of the venom of B. gabonica and B. $g$. rhinoceros demonstrated the presence of BPPs [30].

In this study, the low molecular mass fraction of $B . g$. rhinoceros venom was characterized by SEC, RP-HPLC, LC-MS/MS and bioassay. This strategy led to the identification of a novel non-canonical BPP, named BPP-10 g-AP.

The first ever described BPP, isolated from Bothrops jararaca venom, became the precursor for the development of anti-hypertensive drugs, such as Captopril ${ }^{\circ}$ and Lisinopril $^{\odot}$ [22]. After the discovery of these first BPPs, similar proline-rich peptides were isolated from different snake venoms [31-34] and even frogs skin secretion [35, 36].

According to the kinetic assay, BPP-10 g-AP had inhibitory activity on ACE with a Ki of $1 \mu \mathrm{M}$, a much higher value than Captopril $^{\circ}$, which displays a $\mathrm{Ki}$ of $0.046 \mu \mathrm{M}$ [37]. Thus, although the inhibitory effect is believed to be associated with the presence of hydrophobic residues at the $\mathrm{C}$-terminal region of the peptide, the $\mathrm{N}$ terminal region (which usually starts with a pyroglutamic acid) may be important for affinity/specificity.

$\mathrm{BK}$, as well as other kinins, presents several pharmacological actions such as vascular permeability alterations. Blood pressure drop induced by BK results from a 


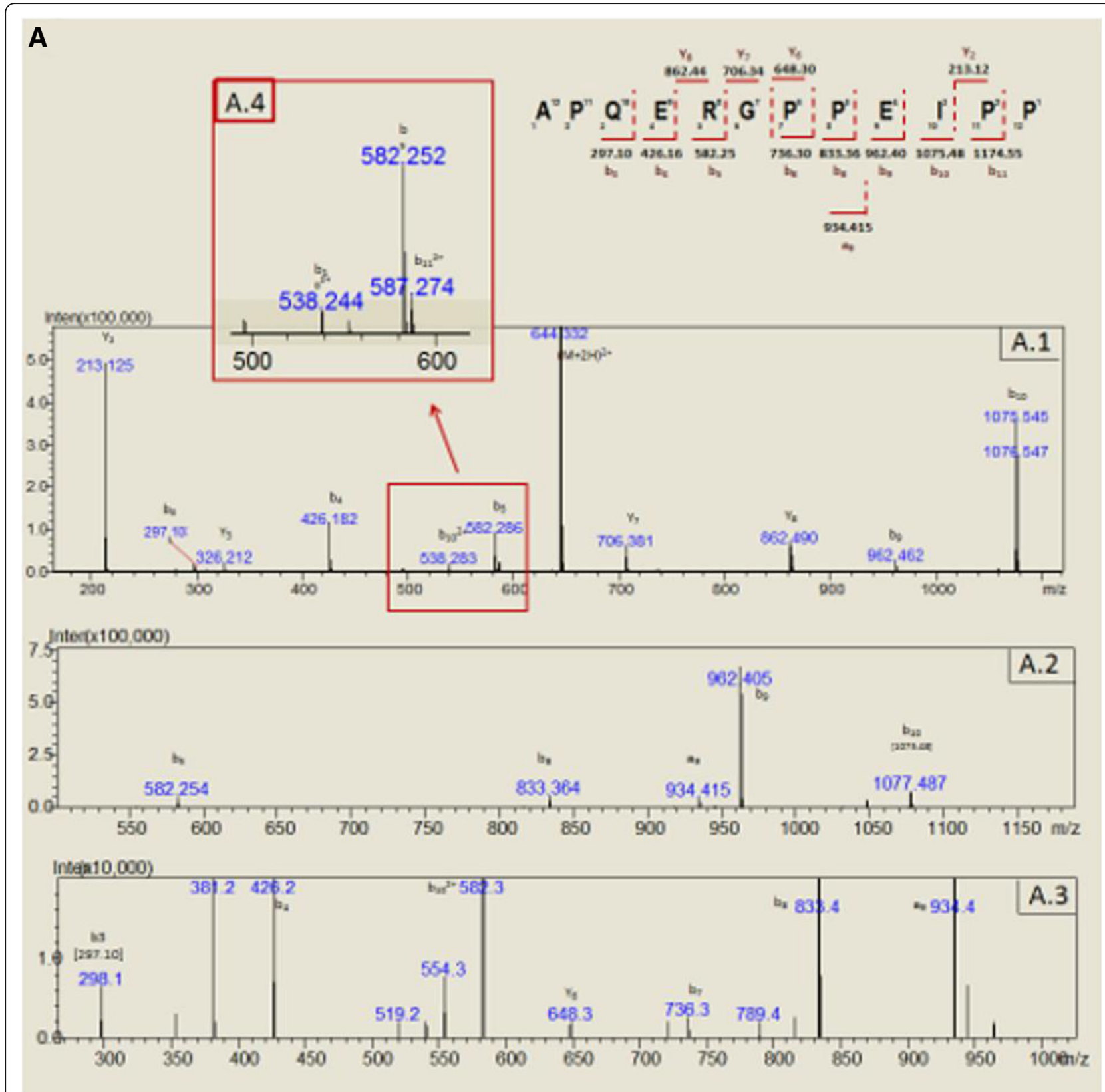

Fig. 3 Representative CIF spectra of $m / z=644.30[M+2 H]^{2+}$, (A.1) $M S^{2}$ for $m / z=644.30$, (A.2) $M S^{3}$ for $m / z=1075.545$, (A.3) $M S^{4}$ for $m / z=962.405$, (A.4) magnification of A.2 and respective annotations and sequence deduction

decrease of vascular resistance in different organs such as heart, kidneys, intestine, skeletal muscles and liver [38].

Kinins trigger the increase of capillary flow, enabling the liquid exit from blood to tissues. This efflux can be facilitated by several factors such as increased vascular permeability and increase of the venous pressure, leading to liquid and proteins accumulation in the extravascular space, resulting in edema. Thus, one manner to investigate the activity of BK is to measure its edematogenic properties [37].

The synthetic BPP clearly induced an increase of the edematogenic activity of BK in our animal model. A previous study, using a similar approach, showed that the peptide KPP (kinin potentiating peptide, generated by tryptic digestion of human plasma proteins) and $B$. jararaca BPP9a (QWAQWPRPQIPP) induced intense and fast paw edema, similarly to our results [7].

Besides the new BPP, we identified one other BPP by de novo sequencing in $B . g$. rhinoceros venom (<ENWPRPQIPP), identical to $B$. jararaca BPP-10b. Interestingly, another peptide $\left(\mathrm{m} / \mathrm{z}=591.76[\mathrm{M}+2 \mathrm{H}]{ }^{2+}\right)$ that was only partially sequenced (data not shown) presented a typical y2 ion (PP) and displays a valine instead 


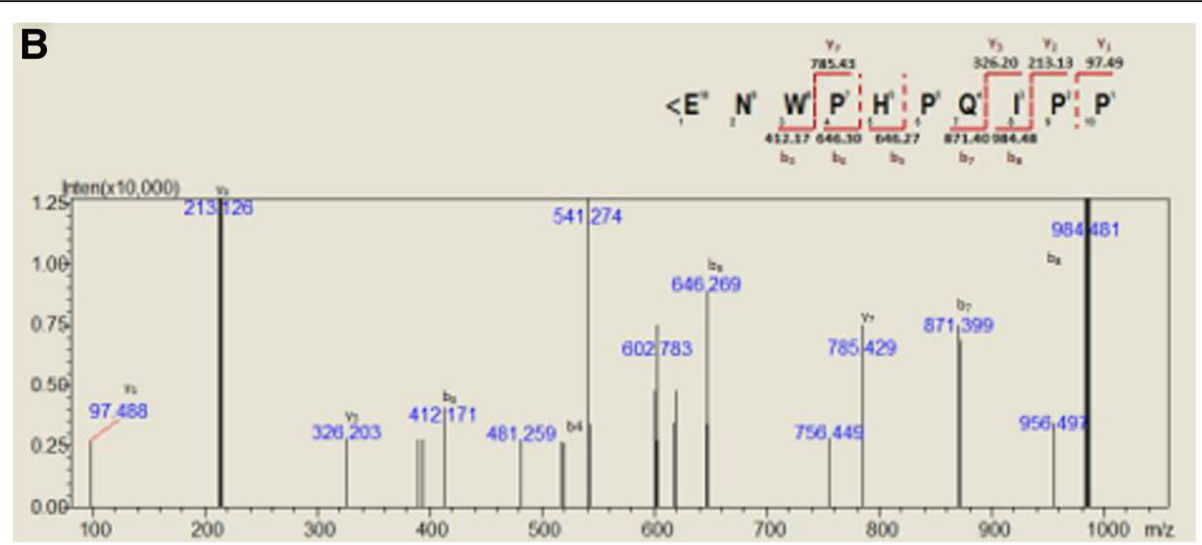

Fig. 4 Representative CIF spectra of $m / z=984.48[M+2 H]^{2+}$ and respective annotations and sequence deduction

of isoleucine in the conserved IPP C-terminus. Calvete et al. [27] and Komori et al. [39] identified a similar Cterminal tripeptide in BPPs isolated from the venoms of Vipera ammodytes meridionalis and $V$. a. aspis respectively. Thus, so far, this BPP variant seems to be restricted to the Viperinae subfamily. The diversity of BPPs in a single venom has been ascribed to gene duplication and accelerated evolution within the BPP precursor gene [40]. It is therefore possible that the VPP motif has evolved after the split between Crotalinae and Viperinae. The occurrence of this VPP motif instead of the highly conserved IPP in the venoms of three dissimilar species strongly suggests that its presence is not accidental, indicating that there is some evolutionary advantage for the presence of BPPs with this sequence in snake venoms.

Snake venoms are composed by a mixture of components such as peptidases, phospholipases $\mathrm{A}_{2}$, myotoxins, neurotoxins and vasoactive peptides, which act synergistically, promoting a collapse of homeostasis [41]. These components interact with key physiological processes, leading to coagulopathies (peptidases, some phospholipases $\mathrm{A}_{2}$ ), tissue degradation (peptidases, phospholipases $\mathrm{A}_{2}$, myotoxins) and inhibition of the neuromuscular transmission [41]. In this context, BPPs play a key role in envenomation, by inducing severe hypotension and contributing for prey immobilization.

Small peptides, such as BPPs, are interesting and promising molecules from the biotechnological perspective. Especially when nature presents variations on the theme (such as BPP-10 g-AP N-terminal -AP-) providing a breath of fresh air in the continuous search of new anti-hypertensive molecules that would be either more potent or more selective to the $\mathrm{C}$-domain.

\section{Conclusions}

To the best of authors' knowledge, this is the first identification of a canonical BPP in the Bitis genus. Such discovery is greatly dependent on both proper sample preparation and contemporary analytical techniques. Accordingly, BPP-10 g-AP amino acid sequence could only be deduced by mass spectrometry using the information gathered by $\mathrm{MS}^{3}$ and $\mathrm{MS}^{4}$, due to presence of two glutamic acids in the sequence that, according to our interpretation, impaired the ionization of the daughter fragments, yielding a non-informative spectrum (Fig. 3). It was only when $\mathrm{MS}^{4}$ was used that the full peptide sequence could be deduced. This emphasizes the importance of ion trap mass analyzers as tools for the discovery and characterization of new molecules.

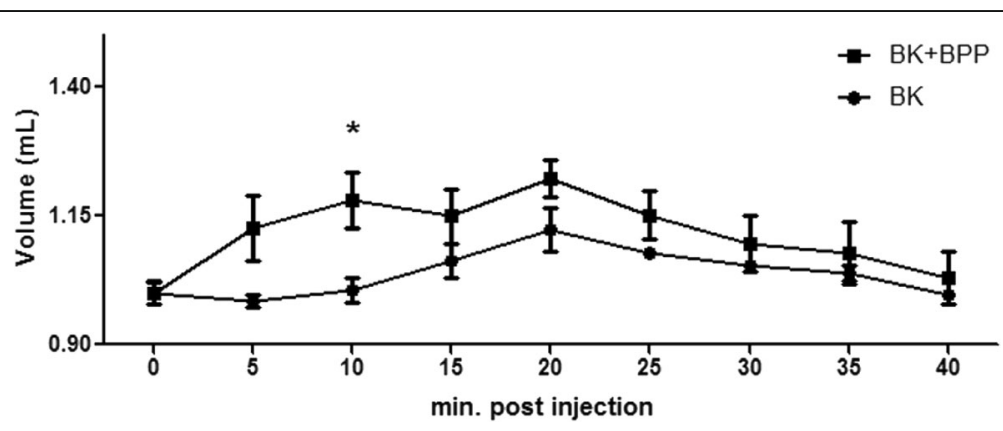

Fig. 5 Rat paw edema induced by BK and BK in the presence of BPP-10 g-AP 


\section{Abbreviations}

ACE: Angiotensin-I converting enzyme; Ang II: Angiotensin II; BK: Bradykinin BPP: Bradykinin-potentiating peptide; FRET: Fluorescence resonance energy transfer; MS: Mass spectrometry; $\mathrm{MS}^{2}: 1^{\text {st }}$ Generation product ion spectra; $\mathrm{MS}^{3}: 2^{\text {nd }}$ Generation product ion spectra; $\mathrm{MS}^{4}: 3^{\text {rd }}$ Generation product ion spectra; SEC: Size exclusion chromatography; TFA: Trifluoroacetic acid

\section{Funding}

The presented study was supported by the Coordination for the Improvement of Higher Education Personnel (CAPES) and the Financier of Studies and Projects (Finep - Convênio Finep 01.09.0278.00).

\section{Authors' contributions}

TMF performed the aqueous chromatographic procedures, and contributed to the enzymatic and in vivo assays and to the elaboration of the manuscript. JMS contributed to the de novo sequencing, in vivo and enzymatic assays and to the writing of the manuscript. IC contributed with the RP-HPLC assays, as well as with the enzymatic assays. VLV contributed with the de novo sequence analysis and with the final writing of the manuscript. BBC contributed with all the purification steps. DCP coordinated all the peptide characterization procedures and was involved in the final edition of the manuscript. PJS provided the venom, developed the aqueous chromatography procedures and participated in the final edition of the manuscript. All authors read and approved the final manuscript.

\section{Competing interests}

The authors declare that they have no competing interests.

\section{Consent for publication}

Not applicable.

\section{Ethics approval and consent to participate}

Procedures involving animals and their care were in accordance with the guidelines for the use of animals on biomedical research and were approved by the Animal Ethics Committee (protocol 171/16) of IPEN.

\section{Publisher's Note}

Springer Nature remains neutral with regard to jurisdictional claims in published maps and institutional affiliations.

\section{Author details}

'Biotechnology Center, Nuclear and Energy Research Institute (IPEN), Av. Lineu Prestes, 2242, São Paulo, SP CEP 05508-000, Brazil. ' Laboratory of Biochemistry and Biophysics, Butantan Institute, Av. Vital Brasil, 1500, São Paulo, SP CEP 05503-900, Brazil.

Received: 24 November 2016 Accepted: 14 June 2017 Published online: 26 June 2017

\section{References}

1. Favreau P, Cheneval O, Menin L, Michalet S, Gaertner H, Principaud F, et al. The venom of the snake genus Atheris contains a new class of peptides with clusters of histidine and glycine residues. Rapid Commun Mass Spectrom. 2007;21(3):406-12.

2. Pimenta DC, Prezoto BC, Konno K, Melo RL, Furtado MF, Camargo AC, et al. Mass spectrometric analysis of the individual variability of Bothrops jararaca venom peptide fraction. Evidence for sex-based variation among the bradykinin-potentiating peptides. Rapid Commun Mass Spectrom. 2007; 21(6):1034-42

3. Konno K, Picolo G, Gutierrez VP, Brigatte P, Zambelli VO, Camargo ACM, et al. Crotalphine, a novel potent analgesic peptide from the venom of the South American rattlesnake Crotalus durissus terrificus. Peptides. 2008;29(8):1293-304.

4. Zelanis A, Tashima AK, Rocha MM, Furtado MF, Camargo AC, Ho PL, et al. Analysis of the ontogenetic variation in the venom proteome/peptidome of Bothrops jararaca reveals different strategies to deal with prey. J Proteome Res. 2010;9(5):2278-91.

5. Tashima AK, Zelanis A, Kitano ES, lanzer D, Melo RL, Rioli V, et al. Peptidomics of three Bothrops snake venoms: insights into the molecular diversification of proteomes and peptidomes. Mol Cell Proteomics. 2012;11(11):1245-62.
6. Munawar A, Zahid A, Negm A, Akrem A, Spencer P, Betzel C. Isolation and characterization of Bradykinin potentiating peptides from Agkistrodon bilineatus venom. Proteome Sci. 2016;14:1-9.

7. Fernandez JH, Neshich G, Camargo ACM. Using bradykinin-potentiating peptide structures to develop new antihypertensive drugs. Genet Mol Res. 2004;3(4):554-63.

8. Clemetson KJ, Lu Q, Clemetson JM. Snake venom proteins affecting platelets and their applications to anti-thrombotic research. Curr Pharm Des. 2007; 13(28):2887-92

9. Rocha e Silva M, Beraldo WT, Rosenfeld G. Bradykinin, a hypotensive and smooth muscle stimulating factor released from plasma globulin by snake venoms and by trypsin. Am J Physiol. 1949;156(2):261-73.

10. Couture R, Harrisson M, Vianna RM, Cloutier F. Kinin receptors in pain and inflammation. Eur J Pharmacol. 2001;429(1-3):161-76.

11. Cyr M, Lepage Y, Blais Jr C, Gervais N, Cugno M, Rouleau JL, et al. Bradykinin and des-Arg(9)-bradykinin metabolic pathways and kinetics of activation of human plasma. Am J Physiol Heart Circ Physiol. 2001;281(1):H275-83.

12. Calixto JB, Cabrini DA, Ferreira J, Campos MM. Kinins in pain and inflammation. Pain. 2000;87(1):1-5.

13. lanzer D, Konno K, Marques-Porto R, Portaro FCV, Stocklin R, Camargo ACM, et al. Identification of five new bradykinin potentiating peptides (BPPs) from Bothrops jararaca crude venom by using electrospray ionization tandem mass spectrometry after a two-step liquid chromatography. Peptides. 2004; 25(7):1085-92.

14. Fuchs S, Xiao HD, Hubert C, Michaud A, Campbell DJ, Adams JW, et al. Angiotensin-converting enzyme C-terminal catalytic domain is the main site of angiotensin I cleavage in vivo. Hypertension. 2008;51(2):267-74.

15. Acharya KR, Sturrock ED, Riordan JF, Ehlers MR. Ace revisited: a new target for structure-based drug design. Nat Rev Drug Discov. 2003;2(11):891-902.

16. Cerdà-Costa N, Gomis-Rüth FX. Architecture and function of metallopeptidase catalytic domains. Protein Sci. 2014;23(2):123-44.

17. Shi L, Mao C, Xu Z, Zhang L. Angiotensin-converting enzymes and drug discovery in cardiovascular diseases. Drug Discov Today. 2010;15(9-10):332-41.

18. Bernstein KE, Shen XZ, Gonzalez-Villalobos RA, Billet S, Okwan-Duodu D, Ong $F S$, et al. Different in vivo functions of the two catalytic domains of angiotensin-converting enzyme (ACE). Curr Opin Pharmacol. 2011;11(2):105-11.

19. Theakston RD, Kamiguti AS. A list of animal toxins and some other natural products with biological activity. Toxicon. 2002:40(5):579-651.

20. Ferreira SH, Bartelt DC, Greene LJ. Isolation of bradykinin-potentiating peptides from Bothrops jararaca venom. Biochemistry. 1970;9(13):2583-93.

21. Stewart JM, Ferreira SH, Greene LJ. Bradykinin potentiating peptide PCA-LysTrp-Ala-Pro. An inhibitor of the pulmonary inactivation of bradykinin and conversion of angiotensin I to II. Biochem Pharmacol. 1971;20(7):1557-67.

22. Cushman DW, Ondetti MA. History of the design of captopril and related inhibitors of angiotensin converting enzyme. Hypertension. 1991;17(4):589-92.

23. Camargo AC, lanzer D, Guerreiro JR, Serrano SM. Bradykinin-potentiating peptides: beyond captopril. Toxicon. 2012;59(4):516-23.

24. Carmona AK, Schwager SL, Juliano MA, Juliano L, Sturrock ED. A continuous fluorescence resonance energy transfer angiotensin l-converting enzyme assay. Nat Protoc. 2006;1(4):1971-6.

25. Menin L, Perchuć A, Favreau P, Perret F, Michalet S, Schöni R, et al. High throughput screening of bradykinin-potentiating peptides in Bothrops moojeni snake venom using precursor ion mass spectrometry. Toxicon. 2008;51(7):1288-302.

26. Georgieva D, Arni RK, Betzel C. Proteome analysis of snake venom toxins: pharmacological insights. Expert Rev Proteomics. 2008;5(6):787-97.

27. Calvete JJ, Escolano J, Sanz L. Snake venomics of Bitis species reveals large intragenus venom toxin composition variation: application to taxonomy of congeneric taxa. J Proteome Res. 2007;6(7):2732-45.

28. Munawar A, Trusch M, Georgieva D, Spencer P, Frochaux V, Harder S, et al Venom peptide analysis of Vipera ammodytes meridionalis (Viperinae) and Bothrops jararacussu (Crotalinae) demonstrates subfamily-specificity of the peptidome in the family Viperidae. Mol Biosyst. 2011;7(12):3298-307.

29. Fasoli E, Sanz L, Wagstaff S, Harrison RA, Righetti PG, Calvete JJ. Exploring the venom proteome of the African puff adder, Bitis arietans, using a combinatorial peptide ligand library approach at different pHs. J Proteomics. 2010;73(5):932-42.

30. Calvete JJ, Marcinkiewicz C, Sanz L. Snake venomics of Bitis gabonica gabonica. Protein family composition, subunit organization of venom toxins, and characterization of dimeric disintegrins bitisgabonin-1 and bitisgabonin-2. J Proteome Res. 2007;6(1):326-36. 
31. Wermelinger LS, Dutra DL, Oliveira-Carvalho AL, Soares MR, Bloch C, Zingali RB. Fast analysis of low molecular mass compounds present in snake venom: identification of ten new pyroglutamate-containing peptides. Rapid Commun Mass Spectrom. 2005;19(12):1703-8.

32. Soares MR, Oliveira-Carvalho AL, Wermelinger LS, Zingali RB, Ho PL, Junqueira-de-Azevedo ILM, et al. Identification of novel bradykinin-potentiating peptides and C-type natriuretic peptide from Lachesis muta venom. Toxicon. 2005:46(1):31-8.

33. Coutinho-Neto A, Caldeira CA, Souza GH, Zaqueo KD, Kayano AM, Silva RS, et al. ESI-MS/MS identification of a bradykinin-potentiating peptide from Amazon Bothrops atrox snake venom using a hybrid Qq-oaTOF mass spectrometer. Toxins (Basel). 2013;5(2):327-35.

34. Munawar A, Trusch M, Georgieva D, Hildebrand D, Kwiatkowski M, Behnken $H$, et al. Elapid snake venom analyses show the specificity of the peptide composition at the level of genera Naja and Notechis. Toxins (Basel). 2014; 6(3):850-68.

35. Conceição K, Konno K, de Melo RL, Antoniazzi MM, Jared C, Sciani JM, et al. Isolation and characterization of a novel bradykinin potentiating peptide (BPP) from the skin secretion of Phyllomedusa hypochondrialis. Peptides. 2007;28(3):515-23.

36. Conceição K, Bruni FM, Sciani JM, Konno K, Melo RL, Antoniazzi MM, et al. Identification of bradykinin - related peptides from Phyllomedusa nordestina skin secretion using electrospray ionization tandem mass spectrometry after a single-step liquid chromatography. J Venom Anim Toxins incl Trop Dis. 2009;15(4):633-52. http://www.scielo.br/scielo.php?script=sci_arttext\&pid= S1678-91992009000400004.

37. DeLucia R. Farmacologia integrada. Ed. Clube de Autores; 2008.

38. Margolius HS. Kallikreins and Kinins. Some unanswered questions about system characteristics and roles in human disease. Hypertension. 1995;26:221-9.

39. Komori Y, Sugihara H. Characterization of a new inhibitor for angiotensin converting enzyme from the venom of Vipera aspis aspis. Int J Biochem. 1990;22(7):767-71.

40. Gomes CL, Konno K, Conceição IM, lanzer D, Yamanouye N, Prezoto BC, et al. Identification of novel bradykinin-potentiating peptides (BPPs) in the venom gland of a rattlesnake allowed the evaluation of the structurefunction relationship of BPPs. Biochem Pharmacol. 2007;74(9):1350-60.

41. Mackessy SP. The field of reptile toxinology-snakes, lizards, and their venoms. In: Mackessy SP, editor. Handbook of venoms and toxins of reptiles. Boca Raton: CRC press; 2009. p. 3-23.

\section{Submit your next manuscript to BioMed Central and we will help you at every step:}

- We accept pre-submission inquiries

- Our selector tool helps you to find the most relevant journal

- We provide round the clock customer support

- Convenient online submission

- Thorough peer review

- Inclusion in PubMed and all major indexing services

- Maximum visibility for your research

Submit your manuscript at www.biomedcentral.com/submit

) Biomed Central 